\title{
ANALISIS PENERAPAN ASEAN-INDIA FREE TRADE AREA (AIFTA) TERHADAP PERDAGANGAN DUA NEGARA INDONESIA DENGAN INDIA MENGGUNAKAN GRAVITY MODEL
}

\author{
Ivan Yuliantoa, Janes Guratan Djermorb \\ aBadan Pendidikan dan Pelatihan Keuangan, Jakarta, Indonesia; \\ Email: iphan7770@yahoo.com \\ bDirektorat Jenderal Bea dan Cukai, Jakarta, Indonesia; \\ Email: janesgdjermor@gmail.com (penulis berkorespondensi)
}

\section{INFO ARTIKEL}

\section{SEJARAH ARTIKEL}

Diterima Pertama

17 September 2018

Dinyatakan Dapat Dimuat

18 Desember 2018

\section{KATA KUNCI:}

AIFTA;

Free Trade Area;

Gravity Model.

\begin{abstract}
ABSTRAK
The ASEAN-India Free Trade Area (AIFTA) policy has been effectively run since January 1 , 2010. It is time to evaluate its benefits for trade relations between its members, especially between Indonesia and India. Analysis of the effectiveness and benefits of AIFTA policy in this study uses the Gravity Model by calculating the variables of Indonesia's GDP, India's GDP, transportation costs, and AIFTA's policies enggaged in trade relations between Indonesia and India using data from first quarter of 2004 until first quarter of 2018. This research shows that implementation of AIFTA does not have any effect on trade between two countries since trade between them had already reaching normal level. This research wishes to give a better insight on policy taking, especially for ongoing and forthcoming trade agreement.
\end{abstract}

Kebijakan ASEAN-India Free Trade Area (AIFTA) sudah berlaku efektif sejak tanggal 1 Januari 2010, untuk itu sudah saatnya dilakukan evaluasi manfaatnya bagi hubungan dagang antar anggotanya, khususnya antara Indonesia dengan India. Analisis efektifitas dan manfaat kebijakan AIFTA dalam penelitian ini menggunakan Gravity Model dengan memperhitungkan variabel GDP Indonesia, GDP India, biaya transportasi, dan kebijakan AIFTA yang diimplementasikan pada hubungan dagang antara Indonesia dan India pada periode kuarter pertama 2004 sampai kuarter pertama 2018. Penelitian ini menunjukkan bahwa penerapan AIFTA tidak memiliki pengaruh terhadap perdagangan di antara dua negara karena tingkat perdagangan di antara dua negara telah mencapai titik normal. Penelitian ini diharapkan untuk memberi sudut pandang bagi para pengambil keputusan untuk dapat mengambil kebijakan lebih baik terhadap perjanjian dagang, baik yang sedang berlangsung ataupun yang akan disepakati. 


\section{PENDAHULUAN}

\subsection{Latar Belakang}

Indonesia dan India tergabung dalam kerja sama dagang regional ASEAN-India Free Trade Area (AIFTA) yang ditandatangani pada pertemuan ke-41 tingkat menteri ekonomi ASEAN pada tanggal 13 Agustus 2009 di Bangkok. AIFTA yang berlaku efektif sejak tanggal 1 Januari 2010 ini diharapkan akan meningkatkan hubungan ekonomi kedua belah pihak di masa datang. AIFTA dilatarbelakangi oleh keinginan dari kedua belah pihak untuk meningkatkan hubungan ekonomi di Asia-Pasifik. Kebijakan look east dari India ternyata sejalan dengan keinginan ASEAN untuk memperluas pasarnya ke arah barat. AIFTA memberikan fasilitas kepada India berupa penghapusan secara berkala sekitar $46,17 \%$ pos tarif negara-negara ASEAN sampai tahun 2018. India juga memberikan penghapusan tarif terhadap barang-barang dari ASEAN. Tarif yang dihapuskan India sebesar 70,18\% pos tarif sampai tahun 2013 dan akan ditingkatkan menjadi 79,35\% dari pos tarif pada tahun 2016 .

$$
\text { Berdasarkan Framework Area on }
$$

Comprehensive Economic Cooperation between the Republic of India and the Association of Southeast Asian Nations, AIFTA bertujuan untuk: (1) Mempererat dan meningkatkan kerja sama di bidang ekonomi, perdagangan, dan investasi; (2) Mempromosikan perdagangan barang dan jasa serta menciptakan suasana investasi yang transparan, liberal, dan fasilitatif; (3) Mencari area baru dan mengembangkan kebijakan yang sesuai untuk membentuk hubungan yang lebih dekat di antara partner; (4) Memfasilitasi integrasi ekonomi yang lebih efektif kepada anggota ASEAN yang baru dan menjembatani gap di antara partner.

Tabel I.1. Perdagangan India dengan negara ASEAN (dalam ribu US\$)

\begin{tabular}{|c|c|c|c|c|c|c|c|}
\hline Exportir & Nilai Impor & Persentase & Importir & Nilai Ekspor & Persentase & Total & Persentase \\
\hline ASEAN & $38,222,455$ & $100 \%$ & ASEAN & $26,381,170$ & $100 \%$ & $64,603,625$ & $100 \%$ \\
\hline Indonesia & $12,189,259$ & $31.89 \%$ & Indonesia & 3,131,503 & $11.87 \%$ & $15,320,762$ & $23.72 \%$ \\
\hline Singapore & $6,719,479$ & $17.58 \%$ & Singapore & $7,354,855$ & $27.88 \%$ & $14,074,334$ & $21.79 \%$ \\
\hline Malaysia & $8,653,351$ & $22.64 \%$ & \begin{tabular}{|l|} 
Malaysia \\
\end{tabular} & $4,188,651$ & $15.88 \%$ & $12,842,002$ & $19.88 \%$ \\
\hline Viet Nam & $3,105,625$ & $8.13 \%$ & Viet Nam & $5,957,677$ & $22.58 \%$ & $9,063,302$ & $14.03 \%$ \\
\hline Thailand & $5,316,378$ & $13.91 \%$ & Thailand & $2,962,384$ & $11.23 \%$ & $8,278,762$ & $12.81 \%$ \\
\hline Myanmar & $1,084,934$ & $2.84 \%$ & Myanmar & $1,141,174$ & $4.33 \%$ & $2,226,108$ & $3.45 \%$ \\
\hline Philippines & 475,844 & $1.24 \%$ & Philippines & $1,474,264$ & $5.59 \%$ & $1,950,108$ & $3.02 \%$ \\
\hline Brunei Darussalam & 461,960 & $1.21 \%$ & Brunei Darussalam & 37,448 & $0.14 \%$ & 499,408 & $0.77 \%$ \\
\hline Laos & 172,412 & $0.45 \%$ & Laos & 23,931 & $0.09 \%$ & 196,343 & $0.30 \%$ \\
\hline Cambodia & 43,213 & $0.11 \%$ & Cambodia & 109,283 & $0.41 \%$ & 152,496 & $0.24 \%$ \\
\hline
\end{tabular}

Sumber: UNCOM Trade, 2018

Perdagangan antara India dengan negaranegara ASEAN menunjukkan pertumbuhan yang baik antara tahun 1993-2003. Perdagangan antara ASEAN dan India pada periode tersebut menunjukkan pertumbuhan rata-rata sebesar $11,2 \%$, dari US $\$ 2,9$ miliar di tahun 1993 sampai US\$12,1 miliar, sebagaimana terlihat pada tabel II.2.

India merupakan partner dagang yang penting bagi Indonesia. Berdasarkan nilai ekspor Indonesia pada tahun 2017, India merupakan negara tujuan ekspor keempat barang-barang Indonesia setelah China, Jepang, dan Amerika Serikat. 8,42\% dari total barang ekspor Indonesia pada tahun 2017 diserap oleh pasar India. Persentase ekspor Indonesia ke India relatif meningkat dalam lima tahun terakhir. Komoditas utama ekspor Indonesia ke India adalah bahan bakar minyak dan gas (migas), minyak nabati dan hewani, bijih besi, karet, dan kertas. Kita dapat melihat bahwa komoditas utama ekspor Indonesia ke India adalah barang-barang yang masih berbentuk bahan baku.

Peningkatan ekspor Indonesia ke India akan berdampak positif terhadap produktifitas dalam negeri. Peningkatan ekspor Indonesia ke India akan berdampak pada meningkatnya produksi barangbarang oleh produsen dalam negeri. Peningkatan produksi dalam negeri akan membawa dampak positif bagi perekonomian nasional berupa penyerapan tenaga kerja dan menurunkan tingkat pengangguran.

Sementara itu, berdasarkan nilai impor Indonesia pada tahun 2017, India merupakan negara asal barang impor kesembilan. Pangsa pasar barang impor India di Indonesia mencakup 2,58\% dari total barang impor Indonesia di tahun 2017. Komoditas utama ekspor India ke Indonesia adalah besi dan baja, kendaraan, bahan kimia, mesin, dan biji-bijian. Kita dapat melihat bahwa India lebih banyak melakukan ekspor ke Indonesia untuk barang-barang berupa barang setengah jadi (medium goods) atau barang jadi (finished goods).

Dapat dilihat dari tabel I.2 bahwa terjadi penurunan terhadap pertumbuhan nilai perdagangan antara India dan Indonesia sebelum dan setelah AIFTA. Nilai total perdagangan Indonesia dengan India selalu tumbuh dalam enam tahun sebelum penerapan AIFTA dengan rata-rata pertumbuhan sebesar $24,04 \%$. Total perdagangan Indonesia dan India sempat mengalami kenaikan setelah penerapan FTA di tahun 2010. Namun delapan tahun setelah AIFTA diimplementasikan, rata-rata pertumbuhan total perdagangan Indonesia dengan India hanya mencapai 4,93\%. Dalam periode enam tahun sebelum AIFTA, nilai ekspor Indonesia ke India dan ekspor India ke Indonesia selalu mengalami kenaikan, bahkan di saat krisis global di tahun 2008 dan 2009. Hal tersebut berbanding terbalik dengan kondisi setelah implementasi AIFTA di tahun 2010. Nilai ekspor Indonesia ke India turun pada periode 2012-2016, sementara nilai ekspor India ke Indonesia turun pada periode 2011-2015. 
Tabel I.2. Perdagangan Indonesia dan India Sebelum dan Setelah AIFTA (ribu US\$)

\begin{tabular}{|l|c|c|c|c|c|c|c|}
\hline \multicolumn{1}{|c|}{ PERDAGANGAN INDONESIA-INDIA SEBELUM AIFTA } \\
\begin{tabular}{|l|c|c|c|c|c|c|c|}
\hline Uraian & $\mathbf{2 0 0 4}$ & $\mathbf{2 0 0 5}$ & $\mathbf{2 0 0 6}$ & $\mathbf{2 0 0 7}$ & $\mathbf{2 0 0 8}$ & $\mathbf{2 0 0 9}$ & $\begin{array}{c}\text { rata-rata } \\
\text { pertumbuhan }\end{array}$ \\
\hline Ekspor Indonesia ke India & $2.427 .664,88$ & $3.018 .949,04$ & $3.610 .442,61$ & $4.840 .346,03$ & $6.431 .337,17$ & $7.599 .637,77$ & $25,81 \%$ \\
\hline Ekspor India ke Indonesia & $1.205 .593,55$ & $1.390 .065,92$ & $1.869 .806,02$ & $1.878 .195,50$ & $2.659 .313,62$ & $3.002 .990,69$ & $20,95 \%$ \\
\hline Neraca Perdagangan & $1.222 .071,33$ & $1.628 .883,12$ & $1.740 .636,59$ & $2.962 .150,53$ & $3.772 .023,55$ & $4.596 .647,08$ & $31,91 \%$ \\
\hline Total Perdagangan & $3.633 .258,43$ & $4.409 .014,96$ & $5.480 .248,63$ & $6.718 .541,53$ & $9.090 .650,79$ & $10.602 .628,46$ & $24,04 \%$ \\
\hline
\end{tabular}
\end{tabular}

PERDAGANGAN INDONESIA-INDIA SETELAH AIFTA

\begin{tabular}{|c|c|c|c|c|c|c|c|c|c|}
\hline Uraian & 2010 & 2011 & 2012 & 2013 & 2014 & 2015 & 2016 & 2017 & $\begin{array}{c}\text { rata-rata } \\
\text { pertumbuhan }\end{array}$ \\
\hline Ekspor Indonesia ke India & $9.695 .329,24$ & $13.964 .662,74$ & $14.068 .290,61$ & $14.984 .084,23$ & $15.184 .884,09$ & $13.902 .024,96$ & 12.189.258,70 & $14.084 .131,45$ & $6,77 \%$ \\
\hline Ekspor India ke Indonesia & $4.557 .082,70$ & $6.400 .247,75$ & $6.021 .917,54$ & $5.557 .938,59$ & $4.444 .760,18$ & $2.868 .880,04$ & $3.131 .502,88$ & $4.048 .500,73$ & $1,40 \%$ \\
\hline Neraca Perdagangan & $5.138 .246,54$ & $7.564 .414,99$ & $8.046 .373,07$ & $9.426 .145,64$ & $10.740 .123,91$ & $11.033 .144,92$ & $9.057 .755,82$ & $10.035 .630,71$ & $11,47 \%$ \\
\hline Total Perdagangan & $14.252 .411,94$ & $20.364 .910,49$ & $20.090 .208,15$ & $20.542 .022,82$ & $19.629 .644,27$ & $16.770 .905,00$ & $15.320 .761,58$ & $18.132 .632,18$ & $4,93 \%$ \\
\hline
\end{tabular}

Sumber: UN COM Trade, 2018

Delapan tahun sudah skema kerja sama dagang AIFTA diimplementasikan. Kesepakatan AIFTA tujuan awalnya adalah untuk meningkatkan perdagangan antara negara partner dengan menurunkan hambatan berupa tarif. Namun, keadaan aktual di lapangan menunjukkan pertumbuhan perdagangan antara Indonesia dan India setelah kebijakan setelah AIFTA cenderung turun. Hal tersebut menimbulkan suatu pertanyaan apakah kesepakatan AIFTA berpengaruh terhadap nilai perdagangan antara Indonesia dan India.

\subsection{Rumusan Masalah}

Berdasarkan latar belakang dan ruang lingkup penelitian yang telah diuraikan sebelumnya, maka pertanyaan penelitian yang berusaha dijawab dalam penelitian ini adalah: (1) Bagaimana pengaruh implementasi AIFTA terhadap ekspor Indonesia ke India? (2) Bagaimana pengaruh implementasi AIFTA terhadap ekspor India ke Indonesia?

\subsection{Tujuan Penelitian}

Berdasarkan ruang lingkup dan rumusan maalah yang telah diuraikan, maka penulis berharap tulisan ini dapat mencapai tujuan: (1) Untuk mengetahui pengaruh implementasi AIFTA terhadap ekspor Indonesia ke India; (2) Untuk mengetahui pengaruh implementasi AIFTA terhadap ekspor India ke Indonesia.

\section{KERANGKA TEORITIS DAN PENGEMBANGAN HIPOTESIS}

\subsection{Kerangka Pemikiran}

Peneliti berusaha sebaik mungkin agar di dalam melakukan penelitian dengan tetap mengacu pada kerangka pemikiran yang telah ditetapkan sebelumnya. Kerangka penelitian sebagaimana pada gambar II.1.

\subsection{Gravity Model}

Sebagai alat analisis penulis menggunakan Gravity Model yang diperkenalkan oleh Prof. Jan Tinbergen di tahun 1962 dalam bukunya Shaping the World Economy. Model yang diajukan Jan Tinbergen disebut gravity model karena diinspirasi dari hukum gravitasi fisika yang diajukan Sir Isaac Newton. Jan Tinbergen mengatakan bahwa faktor-faktor yang menentukan nilai perdagangan antara dua negara adalah besarnya ekonomi negara asal barang ekspor dan negara tujuan barang ekspor serta jarak antara pusat ekonomi kedua negara. Secara matematis, gravity model yang diajukan Jan Tinbergen didefinisikan sebagai berikut:

$$
\operatorname{Exp}_{\mathrm{ij}}=\alpha_{0} \mathrm{GDP}_{\mathrm{i}}{ }^{\beta 1} \mathrm{GDP}_{\mathrm{j}}{ }^{\beta 2} \mathrm{D}_{\mathrm{ij}} \boldsymbol{\beta}^{3}
$$

dimana:

$\operatorname{Exp}_{\mathrm{ij}}=$ Ekspor dari negara $\mathrm{i}$ ke negara $\mathrm{j}$

$\mathrm{GDP}_{\mathrm{i}}=$ GDP negara $\mathrm{i}$

$\mathrm{GDP}_{\mathrm{j}}=\mathrm{GDP}$ negara $\mathrm{j}$

$D_{\mathrm{ij}}=$ jarak antara pusat ekonomi negara i dan $\mathrm{j}$

$\alpha_{0}=$ konstanta

$\beta 1, \beta 2, \beta 3=$ koefisien korelasi

Menentukan aliran barang antar negara dengan menggunakan gravity model dilakukan dengan menentukan faktor-faktor utama yang berpengaruh terhadap nilai perdagangan di antara dua negara. Menurut Jan Tinbergen, ada tiga faktor yang berpengaruh terhadap perdagangan bilateral negara, yaitu ukuran ekonomi negara asal dan tujuan barang ekspor, serta jarak antar negara. Pendapat Jan Tinbergen didukung oleh Bergstand yang menyatakan bahwa gravity model menggambarkan aliran barang dan jasa dari suatu negara ke negara lain merupakan fungsi dari keseluruhan sumber daya yang tersedia dari kedua negara dan juga biaya transportasi dan hambatan perdagangan lainnya. 


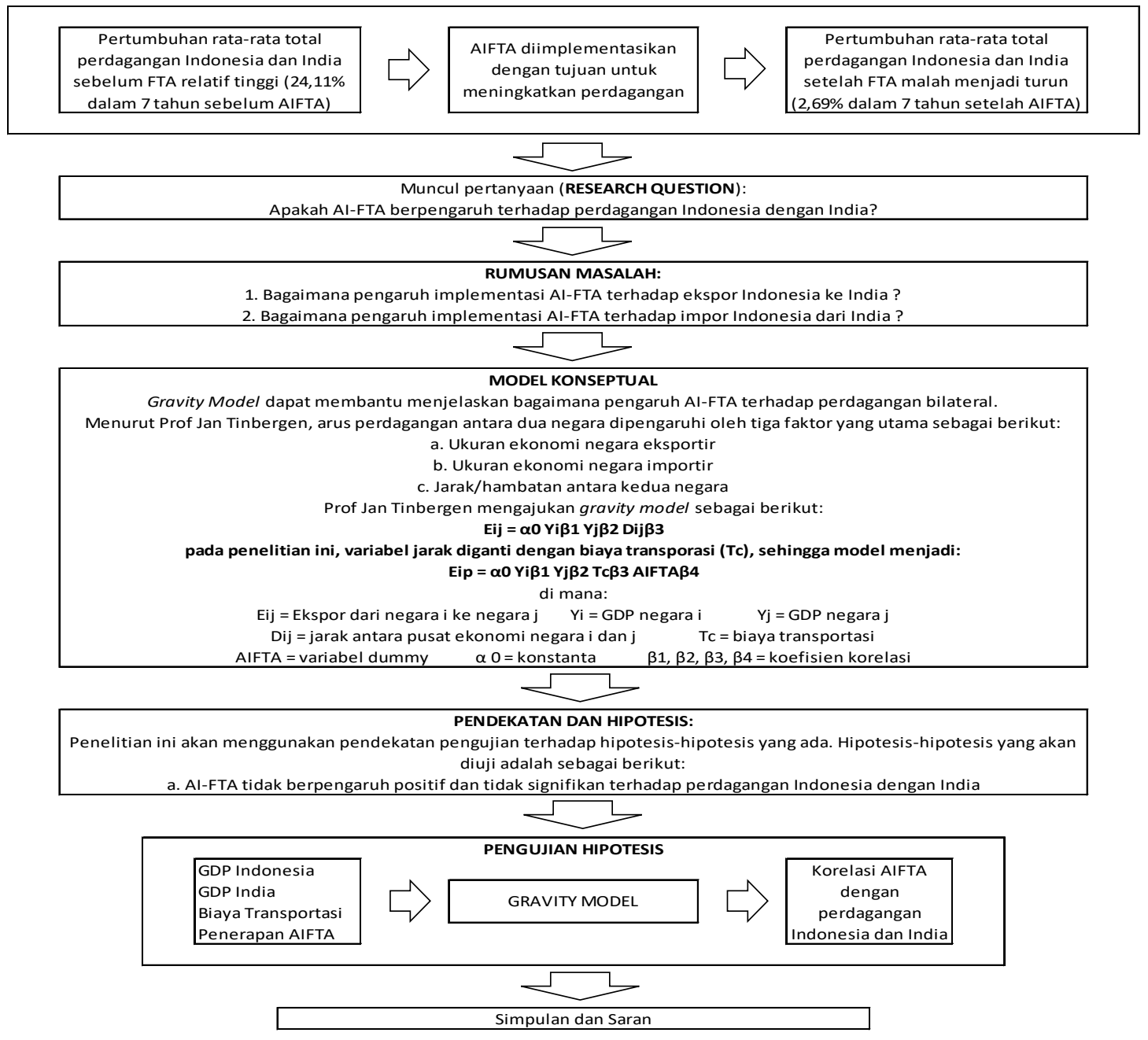

Gambar II.1 Kerangka Pemikiran Penelitian Sumber: Diolah penulis

Jan Tinbergen melakukan analisis dengan menggunakan gravity model dengan tujuan untuk menentukan pola standar atau normal dari perdagangan internasional yang akan terjadi apabila faktor hambatan dari perdagangan internasional dihilangkan. Perbedaan yang muncul antara nilai perdagangan yang diharapkan dan nilai perdagangan riil mengindikasikan bahwa terdapat preferensi atau diskriminasi terhadap ekspor suatu negara. Preferensi terjadi dalam hal terdapat deviasi positif berupa preferensi tarif dari perhitungan dengan menggunakan gravity model. Sementara diskriminasi berupa hambatan terhadap ekspor suatu negara terjadi dalam hal terdapat deviasi negatif dari perhitungan. Studi yang dilakukan oleh Tinbergen sebenarnya bertujuan untuk mencari deviasi, khususnya deviasi negatif yang mengindikasikan adanya hambatan dalam mencapai tingkat perdagangan internasional yang normal.

\section{METODOLOGI PENELITIAN}

\subsection{Penelitian Sebelumnya}

Dalam rangka memperkuat analisis, penulis menggunakan beberapa penelitian terdahulu sebagai rujukan, penelitian tersebut ditampilkan dalam tabel II.3.

\subsection{Jenis dan Sumber Data}

Data yang digunakan pada penelitian ini adalah data sekunder yang meliputi data nilai ekspor Indonesia ke India dan nilai ekspor India ke Indonesia, GDP Indonesia, GDP India, dan rata-rata biaya transportasi tiap ton serta data dummy yang mewakili kesepakatan AIFTA. Data yang digunakan dalam bentuk data time series untuk periode kuarter pertama tahun 2004 sampai dengan kuarter pertama tahun 2018. Data tersebut didapatkan dari Bank Indonesia, Bank Dunia, UNCOM Trade, IMF, Badan Pusat Statistik, dan Kementerian Perdagangan.

\subsection{Variabel Penelitian dan Definisi Operasional}

Penelitian ini menggunakan variabel-variabel sebagai berikut: (1) Nilai ekspor Indonesia ke India adalah total nilai ekspor Indonesia ke India yang mengacu pada nilai Free on Board (FOB) di Indonesia. Satuan yang digunakan adalah juta US\$; (2) Nilai ekspor India ke Indonesia adalah total nilai ekspor India ke Indonesia yang mengacu pada nilai Cost, 
Insurance, and Freight (CIF) dikurangi nilai insurance dan freight di Indonesia (dalam juta US\$); (3) GDP Indonesia adalah nilai Gross Domestic Product Indonesia (dalam juta US\$); (4) GDP India adalah nilai Gross Domestic Product India (dalam juta US\$);(5) Rata-rata biaya transportasi adalah nilai yang dibutuhkan untuk mengangkut suatu barang dari
Indonesia ke India dan dari India ke Indonesia pada periode triwulan (dalam juta US\$); (6) AIFTA adalah data dummy yang melambangkan penerapan AIFTA. Periode sebelum AIFTA diterapkan menggunakan data dummy 0 dan periode setelah AIFTA diterapkan menggunakan data dummy 1.

Tabel II.1 Penelitian Terdahulu Terkait AIFTA maupun Skema Kerja Sama Perdagangan Lainnya

\begin{tabular}{|l|c|c|l||}
\hline \multicolumn{1}{|c|}{ Peneliti } & Tahun & Metode Analisis & \multicolumn{1}{|c||}{ Hasil } \\
\hline Jan Tinbergen & 1962 & Gravity Model & $\begin{array}{l}\text {-British Commonwealth hanya meningkatkan perdagangan sebanyak 4- } \\
5 \% \text { di antara para anggotanya }\end{array}$ \\
\hline $\begin{array}{l}\text { Baier dan } \\
\text { Bergstand }\end{array}$ & 2005 & Gravity Model & $\begin{array}{l}\text { - Tidak ada bukti meyakinkan kalau FTA meningkatkan perdagangan } \\
\text { antara mitra dalam FTA }\end{array}$ \\
\hline Amita Batra & 2006 & Gravity Model & $\begin{array}{l}\text { - Nilai perdagangan yang potensial antara India dan Indonesia telah } \\
\text { dilewati sebelum AIFTA }\end{array}$ \\
\hline Pal dan Dasgupta & 2009 & Kualitatif & $\begin{array}{l}\text { - AlFTA berpengaruh negatif pada sektor industri manufaktur ringan, } \\
\text { perikanan, dan pertanian di India } \\
\text { - AlFTA berpengaruh positif pada sektor industri baja di India } \\
\text { - Pemerintah harus mampu mendistribusikan gain dari industri yang } \\
\text { mendapatkan manfaat kepada industri yang terkena akibat negatif }\end{array}$ \\
\hline
\end{tabular}

Sumber: Diolah penulis.

\section{HASIL DAN PEMBAHASAN}

Data perdagangan Indonesia-India yang diperoleh dari BPS yang digunakan dalam penelitian ini adalah nilai ekspor-impor dengan kondisi Cost, Insurance, and Freight (CIF). Namun, mengingat data ekspor Indonesia masih menggunakan Free on Board (FOB), maka untuk mendapatkan nilai ekspor Indonesia ke India ke dengan kondisi CIF, nilai ekspor Indonesia ke India perlu ditambahkan dengan nilai Insurance (asuransi) dan Freight (biaya transportasi). Untuk menentukan nilai asuransi, maka dasar yang digunakan adalah Peraturan Menteri Keuangan nomor PMK-160/PMK.04/2010 tentang Nilai Pabean untuk Penghitungan Nilai Pabean yang diasumsikan sebesar 1\% dari nilai barang (FOB).

Sedangkan untuk biaya transportasi antara Indonesia-India digunakan data transaksi berjalan pada Neraca Pembayaran Indonesia 2004-2018 periode tiga bulanan. Biaya transportasi ekspor Indonesia ke India dihitung dengan cara mengalikan total jasa transportasi barang (US\$) dengan rasio antara volume perdagangan Indonesia-India dengan total volume perdagangan seluruh negara yang melakukan perdagangan dengan Indonesia (tonase). Diperoleh rata-rata biaya transportasi dari Indonesia ke India pada periode 2004 sampai dengan 2018 adalah sebesar US\$4,68 - 11,85/ton.

Hasil perhitungan rata-rata biaya transportasi per ton untuk mengangkut barang dari Indonesia ke India dan dari India ke Indonesia dapat dilihat pada grafik IV.3 dan grafik IV.4. Rata-rata biaya transportasi barang ekspor Indonesia ke India dan India ke Indonesia relatif stabil pada periode 2004 sampai dengan 2017, dengan fluktuasi pada beberapa periode. Rata-rata biaya transportasi ekspor Indonesia ke India sempat mengalami fluktuasi pada periode 2004 sampai 2006, dan kemudian relatif stabil pada periode 2006 sampai dengan 2017.

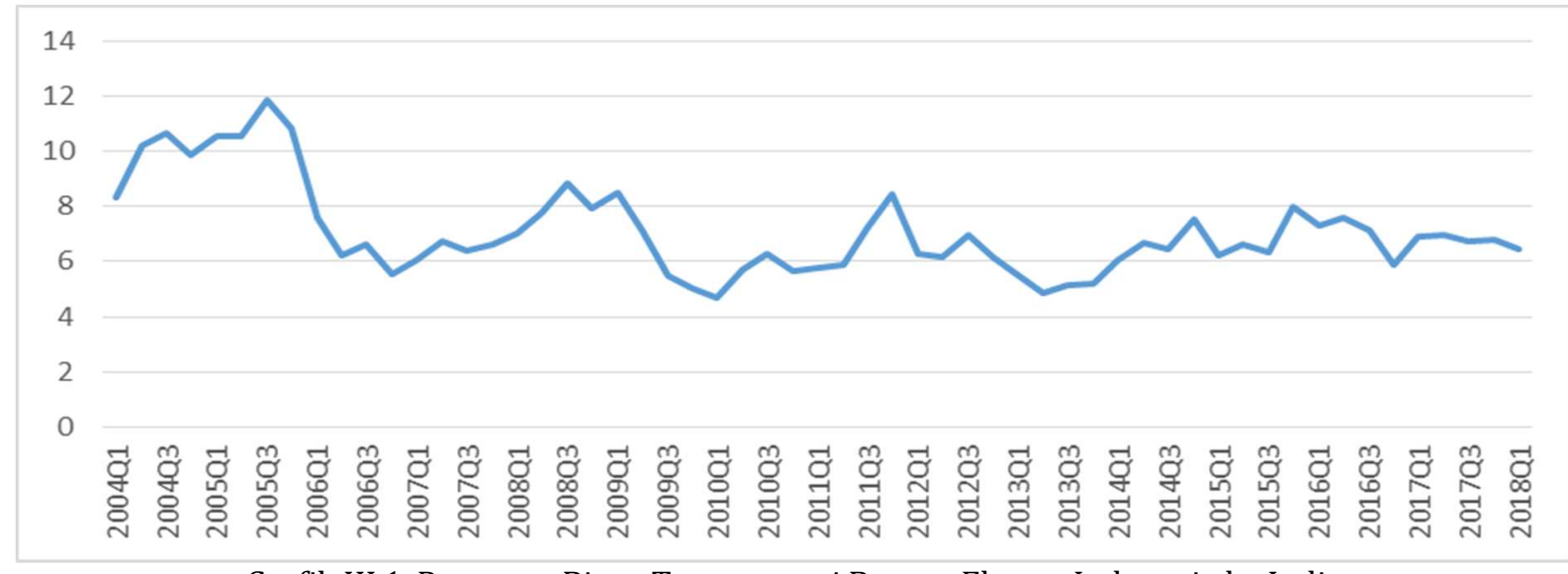

Grafik III.1. Rata-rata Biaya Transportasi Barang Ekspor Indonesia ke India (dalam US\$/ton)

Sumber: Diolah dari Bank Indonesia dan Badan Pusat Statistik (2018) 


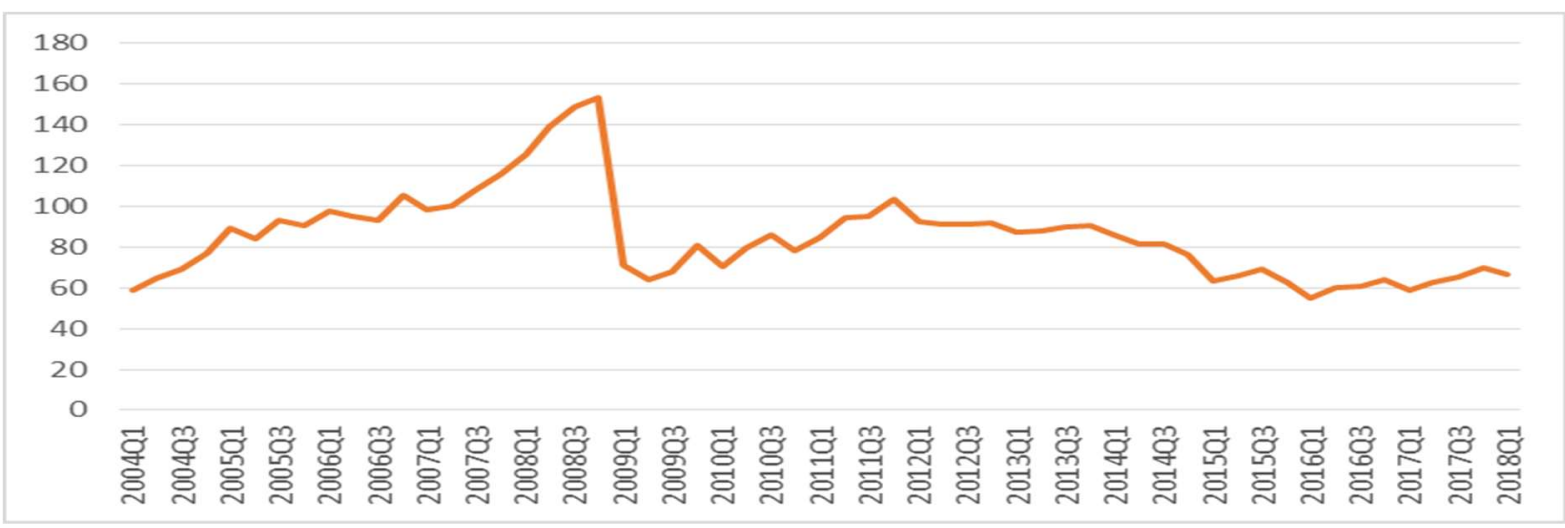

Grafik III.2. Rata-rata Biaya Transportasi Barang Ekspor India ke Indonesia (dalam US\$/ton)

Sumber: Diolah dari Bank Indonesia dan Badan Pusat Statistik (2018)

Sementara itu, rata-rata biaya transportasi ekspor India ke Indonesia pada periode 2004 sampai dengan 2018 sebesar US\$54,94-153,08/ton. Ratarata biaya transportasi ekspor India ke Indonesia cenderung meningkat pada periode 2004 sampai dengan 2008, dan kemudian sempat turun tajam pada periode 2009. Pada periode 2010 sampai dengan 2017, rata-rata biaya transportasi ekspor India ke Indonesia cenderung relatif tidak mengalami fluktuasi yang berarti.

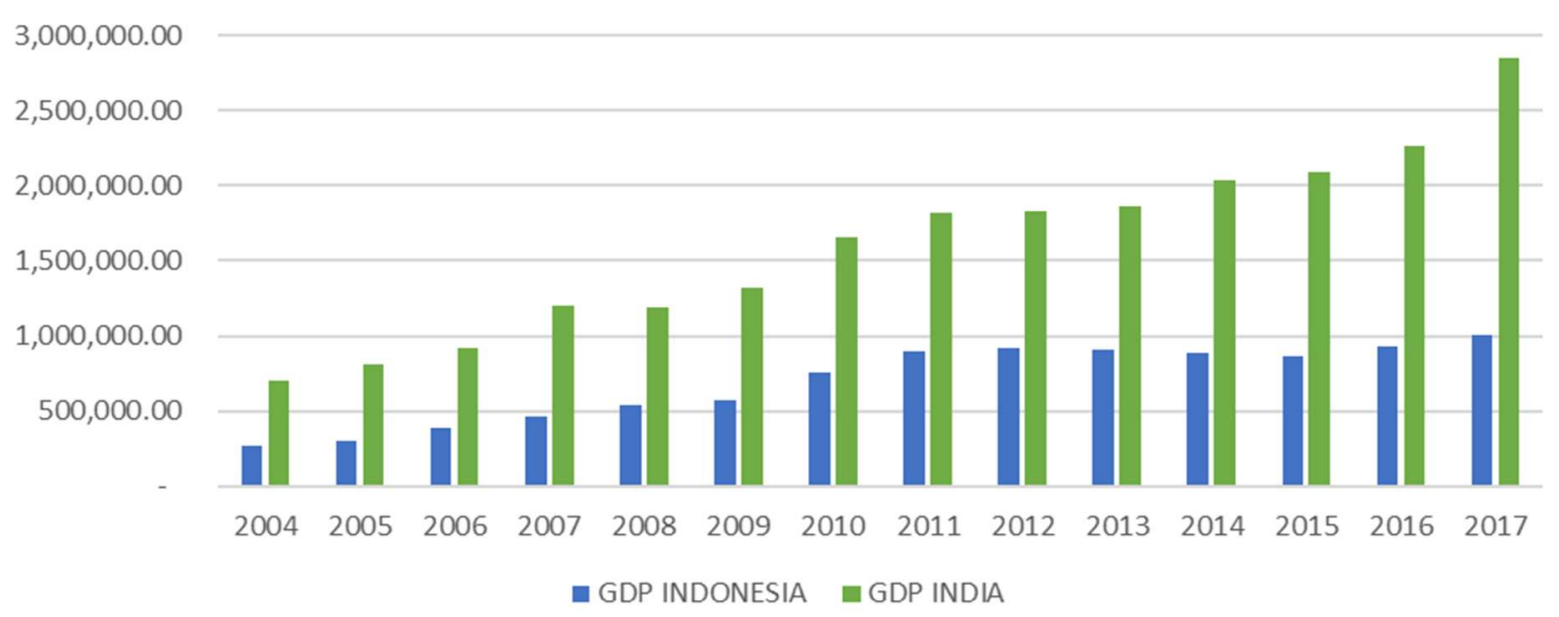

Grafik III.3. GDP Indonesia dan India

Sumber: Diolah dari Bank Indonesia dan Ministry of Planning and Implementation Strategy of India (2018)

Data lain yang digunakan dalam penelitian ini merupakan salah satu indikator perekonomian suatu negara, yaitu Produk Domestik Bruto (PDB) atau biasa disebut Gross Domestic Product (GDP). GDP Indonesia dan India pada periode 2004 dan periode 2017 dapat dilihat pada grafik III.3. GDP India meningkat hampir $400 \%$ pada periode 2004 sampai dengan 2017. GDP India sempat mengalami stagnasi pada periode 2011-2013, tetapi kembali tumbuh pesat pada periode 2014-2017. Sementara itu, GDP Indonesia juga senantiasa bertumbuh pada periode yang sama, meskipun pertumbuhan GDP Indonesia tidak setinggi pertumbuhan GDP India. Pada tahun 2017, GDP India lebih dari 2,5 kali GDP Indonesia.

\subsection{Deskripsi Statistik}

Hasil pengolahan data menggunakan software STATA 14 dapat dilihat pada tabel II.1. Data yang digunakan berupa data time-series dengan periode triwulan pertama 2004 sampai dengan triwulan pertama 2018, sehingga didapatkan 57 observasi.

Variabel bebas berupa kesepakatan AIFTA merupakan data dummy (1 dan 0$)$ yang menggambarkan ada kesepakatan AIFTA dengan angka satu dan tidak ada kesepakatan dengan angka nol. Variabel tersebut memiliki sebaran data sebanyak 24 sampel berupa data tanpa kesepakatan AIFTA dan 33 sampel berupa data dengan penerapan kesepakatan AIFTA. 
Tabel III.1 Deskripsi Statistik Variabel-Variabel Penelitian

\begin{tabular}{|r|rrrrr|}
\hline \multicolumn{6}{|c|}{ summarize exina exindia gdpina gdpindia Tcexina Tcexindia } \\
Variable & Obs & Mean & Std. Dev. & Min & Max \\
\hline exina & 57 & 2247.988 & 1060.131 & 413.3351 & 4017.243 \\
exindia & 57 & 658.9422 & 291.1931 & 181.4658 & 1180.556 \\
gdpina & 57 & 174865.7 & 63875.88 & 63916.26 & 258405.8 \\
gdpindia & 57 & 410023.7 & 160866 & 158696 & 829131.2 \\
Tcexina & 57 & 7.087853 & 1.644377 & 4.682175 & 11.85046 \\
\hline Tcexindia & 57 & 85.18664 & 21.46139 & 54.93768 & 153.08 \\
\hline
\end{tabular}

Sumber: Diolah menggunakan STATA 14 (2018)

\subsection{Pengujian Hipotesis}

Pengujian hipotesis pada penelitian ini menggunakan pengujian regresi berganda terhadap dua model, yang pertama untuk menggambarkan ekspor Indonesia ke India dan model kedua untuk menggambarkan ekspor India ke Indonesia. Model persamaan yang digunakan dalam penelitian ini mengacu pada model yang digunakan oleh Jan Tinbergen sebagai berikut:

4.2.1 Model Ekspor Indonesia ke India:

\section{$\operatorname{Exp}_{\text {ina }}=\alpha_{0}$ GDP $_{\text {ina }}{ }^{\beta 1}$ GDP $_{\text {india }}{ }^{\beta 2}$ Tcexina $^{\beta 3}$ AIFTA $^{\beta 4}$} $\varepsilon$

$\mathrm{H}_{0}$ : Kesepakatan AIFTA tidak memiliki pengaruh terhadap ekspor Indonesia ke India.

4.2.2 Model Ekspor India ke Indonesia:

$\operatorname{Exp}_{\text {india }}=\alpha_{1}$ GDP $_{\text {ina }}{ }^{\beta 5}$ GDP $_{\text {india }}{ }^{\beta 6}$ Tc $_{\text {exindia }}{ }^{\beta 7}$ AIFTA $\beta 8$ $\varepsilon$. (2)

$\mathrm{H}_{0}$ : Kesepakatan AIFTA tidak memiliki pengaruh terhadap ekspor India ke Indonesia

dimana:

$\operatorname{Exp}_{\text {ina }}=$ Ekspor Indonesia ke India

$\operatorname{Exp}_{\text {india }}=$ Ekspor India ke Indonesia

$\mathrm{GDP}_{\text {ina }}=$ GDP negara Indonesia (dalam juta US\$)

$\mathrm{GDP}_{\text {india }}=$ GDP negara India (dalam juta US\$)

$\mathrm{Tc}_{\text {exina }}=$ rata-rata biaya transportasi ekspor Indonesia ke India (dalam US\$/ton)

$\mathrm{TC}_{\text {exindia }}=$ rata-rata biaya transportasi ekspor India Indonesia (dalam US\$/ton)

AIFTA $=$ dummy variabel $($ penerapan AIFTA $=1$; tanpa AIFTA = 0)

$\alpha_{0}, \alpha_{1}=$ konstanta

$\beta 1, \beta 2, \beta 3, \beta 4, \beta 5, \beta 6, \beta 7, \beta 8=$ koefisien korelasi $\varepsilon=$ error

\subsection{Ekspor Indonesia ke India}

Pengujian asumsi klasik yaitu uji kasualitas, uji normalitas, uji heteroskedastis, uji autokorelasi, dan uji multikoliearitas, menunjukkan bahwa data yang digunakan pada penelitian ini telah memenuhi persyaratan asumsi klasik. Oleh karena itu, data-data yang ada dapat digunakan untuk pengujian selanjutnya, yaitu pengujian dalam model regresi berganda. Seperti yang sudah dipaparkan terlebih, model yang digunakan dalam penelitian ini adalah sebagai berikut:

$$
\operatorname{Exp}_{\text {ina }}=\alpha_{0} \text { GDP }_{\text {ina }}{ }^{\beta 1} \text { GDP }_{\text {india }}{ }^{\beta 2} \text { Tc }_{\text {exina }}{ }^{\beta 3} \text { AIFTA }^{\beta 4} \varepsilon
$$

Ada indikasi model mengalami multikolinearitas, sehingga penulis mengambil langkah menghilangkan variabel GDP Indonesia dalam model. Selain itu, variabel bebas dan terikat juga ditransformasi ke dalam bentuk logaritma natural. Bentuk logaritma natural lebih dapat menggambarkan pertumbuhan GDP dan biaya transportasi dari suatu periode dibandingkan dengan periode sebelumnya. Berdasarkan hal tersebut, maka model pengujian menjadi sebagai berikut:

\section{$\log \operatorname{Exp}_{\text {ina }}=\beta 1 \log \mathrm{GDP}_{\text {india }}+\beta 3 \log \mathrm{Tc}_{\text {exina }}+\beta 4$ $\log$ AIFTA $+\log \varepsilon_{\text {in }}+\log \alpha_{0}$}

Selanjutnya, pengujian yang dilakukan dalam model regresi berganda ini akan meliputi uji koefisien determinasi $\left(\mathrm{R}^{2}\right)$, uji keandalan model (uji F), dan uji koefisien(uji t).

4.3.1 Koefisien Determinasi (R-squared)

Dari regresi Nilai Adjusted R-squared berdasarkan hasil pengujian pada Tabel III.2. didapatkan sebesar 0,3832. Hal tersebut menunjukkan bahwa variabel-variabel berupa log GDP India, log rata-rata biaya transportasi ekspor Indonesia ke India, dan log penerapan kesepakatan AIFTA secara simultan mampu menjelaskan 38,32\% variance pada variabel nilai ekspor Indonesia ke India dan 61,689\% sisanya dipengaruhi oleh variabel-variabel lainnya yang tidak terdapat dalam model regresi pada penelitian ini.

Kelayakan model di atas untuk menjelaskan hubungan antara variabel bebas dan terikat dapat dilihat dari nilai probabilitas $\mathrm{F}$ hasil pengujian. Variabel bebas suatu model dikatakan mampu menjelaskan variabel terikatnya secara simultan apabila memiliki nilai prob. F di bawah tingkat signifikasi alpha 5\% dan sebaliknya. Nilai Prob. F pada Tabel III.2 berdasarkan hasil pengujian terhadap model regresi didapatkan mendekati 0 . Nilai tersebut lebih kecil dari tingkat signifikansi alpha 5\%. Berdasarkan hasil tersebut, maka dapat disimpulkan bahwa model regresi layak digunakan untuk menjelaskan pengaruh pertumbuhan GDP India, pertumbuhan rata-rata biaya transportasi 
ekspor Indonesia ke India, dan penerapan kesepakatan AIFTA terhadap pertumbuhan nilai ekspor Indonesia ke India.

Tabel III.2. Hasil Regresi Ekspor Indonesia ke India Setelah Transformasi

\begin{tabular}{r|rcrcrr|}
\hline logexina & Coef. & Std. $\Xi x x$. & $\tau$ & $\mathrm{p}>1 t]$ & \multicolumn{2}{c|}{ [958 Conf. Interval] } \\
\hline loggdpindia & .941444 & .2179962 & 4.32 & 0.000 & .5040026 & 1.378885 \\
logTCexina & -.1104447 & .1907655 & -0.58 & 0.565 & -.4932436 & .2723543 \\
aifta & .1501306 & .1615979 & 0.93 & 0.357 & -.1741393 & .4744006 \\
cons & -4.383978 & 2.778921 & -1.58 & 0.121 & -9.960291 & 1.192334 \\
\hline rho & .7042627 & & & & & \\
\hline
\end{tabular}

Sumber: Diolah menggunakan STATA 14 (2018)

\subsubsection{Uji Signifikasi Parsial (Uji-t)}

Uji t disebut juga uji signifikansi variabel bebas secara individu. Uji t digunakan untuk mengetahui apakah masing-masing variabel bebas dalam model regresi secara parsial berpengaruh terhadap variabel terikat. Uji t juga merupakan indikator yang dapat digunakan untuk melihat apakah parameter yang digunakan untuk mengestimasi suatu model regresi merupakan parameter yang tepat. Suatu variabel bebas dikatakan memiliki pengaruh terhadap variabel terikat apabila memiliki nilai thitung di bawah tingkat signifikasi alpha 5\% dan sebaliknya. hasil pengujian probabilitas thitung dapat dilihat pada tabel III.2.

Variabel $\log$ GDP India memiliki nilai thitung mendekati 0 . Nilai tersebut berada di bawah tingkat signifikansi alpha 5\%. Berdasarkan hal tersebut maka dapat disimpulkan bahwa variabel log GDP India memiliki pengaruh terhadap variabel $\log$ nilai ekspor Indonesia ke India. Dilihat dari koefisien variabel bebas, $\log$ GDP India memiliki koefisien 0,9414 dengan range 0,5040 dan 1,3789 dengan tingkat keyakinan 95\%. Hal tersebut berarti jika variabel bebas lain konstan, maka pertumbuhan nilai ekspor Indonesia diestimasikan akan berubah antara $0,5 \%$ sampai dengan $1,38 \%$ untuk setiap $1 \%$ perubahan GDP India.

Variabel $\log$ rata-rata biaya transportasi ekspor Indonesia ke India memiliki nilai thitung sebesar 0,565 atau 56,5\%. Nilai tersebut berada di atas tingkat signifikansi alpha 5\%. Berdasarkan hal tersebut maka dapat disimpulkan bahwa variabel log rata-rata biaya transportasi ekspor Indonesia ke India tidak memiliki pengaruh terhadap log nilai ekspor Indonesia ke India. Variabel penerapan AIFTA memiliki nilai thitung sebesar 0,357 atau 35,7\%. Nilai tersebut berada sedikit di atas tingkat signifikansi alpha 5\%. Berdasarkan hal tersebut maka dapat disimpulkan bahwa variabel log penerapan AIFTA tidak memiliki pengaruh terhadap variabel $\log$ nilai ekspor Indonesia ke India.

Dengan demikian, dapat disimpulkan bahwa Ho: Kesepakatan AIFTA tidak memiliki pengaruh terhadap ekspor Indonesia ke India, dinyatakan diterima.

\subsection{Ekspor India ke Indonesia}

Pengujian asumsi klasik yang dilakukan terlebih dahulu menunjukkan bahwa data yang digunakan telah memenuhi persyaratan asumsi klasik. Oleh karena itu, data-data yang ada dapat digunakan untuk pengujian selanjutnya, yaitu pengujian dalam model regresi berganda.

Seperti yang sudah dipaparkan terlebih dahulu, model yang digunakan dalam penelitian ini adalah sebagai berikut:

$\operatorname{Exp}_{\text {india }}=\alpha_{0}$ GDP $_{\text {india }}{ }^{\beta 1}$ GDP $_{\text {ina }}{ }^{\beta 2}$ Tcexindia $^{\beta 3}$ AIFTA $^{\beta 4} \varepsilon$

Berdasarkan pengujian non-multikolinearitas disinyalir terjadi multikolineritas, oleh karena itu variabel GDP India ditiadakan. Selain itu, pengujian autokorelasi membutuhkan penerapan prosedur Cochrane-Orcutt di dalam regresi. Berdasarkan hal tersebut, maka model pengujian menjadi sebagai berikut:

$\operatorname{Exp}_{\text {india }}=\alpha_{0}$ GDP $_{\text {ina }}{ }^{\beta 1}$ Tc $_{\text {exindia }^{\beta 2}}$ AIFTA $^{\beta 3} \boldsymbol{\varepsilon}$

Sama seperti model regresi ekspor Indonesia ke India sebelumnya, pengujian yang dilakukan dalam model regresi berganda ekspor India ke Indonesia akan meliputi uji koefisien determinasi $\left(\mathrm{R}^{2}\right)$, uji keterandalan model (uji F), dan uji koefisien regresi (uji t). Hasil pengujian hipotesis untuk menguji hubungan antara variabel GDP India, ratarata biaya transportasi untuk mengangkut barang ekspor India ke Indonesia setelah dilakukan prosedur Cochrane-Orcutt dan penerapan AIFTA terhadap nilai ekspor India ke Indonesia dapat dilihat pada tabel III.3.

\subsubsection{Koefisien Determinasi (R-squared)}

Nilai Adjusted R-squared berdasarkan hasil pengujian pada Tabel III.2., diperoleh angka sebesar 0,6104 . Hal tersebut menunjukkan bahwa variabelvariabel berupa GDP Indonesia, rata-rata biaya transportasi ekspor India ke Indonesia, dan penerapan kesepakatan AIFTA secara simultan mampu menjelaskan variance pada variabel nilai ekspor India ke Indonesia sebesar $61 \%$ dan sisanya $39 \%$ dipengaruhi oleh variabel lain yang tidak terdapat dalam model regresi pada penelitian ini. Uji Signifikansi Model (Uji-F).

\subsubsection{Uji Signifikansi Model}

Nilai Prob. F pada Tabel III.2. berdasarkan hasil pengujian terhadap model regresi didapatkan sebesar 0,0000. Nilai tersebut lebih kecil dari tingkat signifikansi alpha 5\%. Berdasarkan hasil tersebut, maka dapat disimpulkan bahwa model regresi layak digunakan untuk menjelaskan pengaruh penerapan GDP Indonesia, rata-rata biaya transportasi ekspor India ke Indonesia, dan penerapan kesepakatan AIFTA secara simultan terhadap nilai ekspor India ke Indonesia. 
Tabel III.3. Hasil Regresi Ekspor India ke Indonesia Setelah Transformasi

\begin{tabular}{r|rrrrrr|}
\hline exindia & Coef. & Std. Err. & $t$ & P>lt & [958 Conf. Interval] \\
\hline gdpina & .0034392 & .0009463 & 3.63 & 0.001 & .0015403 & .0053381 \\
ICexindia & 1.979253 & 1.132659 & 1.75 & 0.086 & -.2935942 & 4.252099 \\
aifta & 108.5912 & 119.3803 & 0.91 & 0.367 & -130.963 & 348.1453 \\
_cons & -176.7018 & 150.1736 & -1.18 & 0.245 & -478.0471 & 124.6436 \\
\hline rho & .443967 & & & & & \\
\hline
\end{tabular}

Sumber: Diolah menggunakan STATA 14 (2018)

\subsubsection{Uji Signifikansi Parsial (Uji-t)}

Hasil pengujian probabilitas thitung dapat dilihat pada tabel III.2. variabel GDP Indonesia memiliki nilai thitung sebesar 0,001 atau 0,1\%. Nilai tersebut berada di bawah tingkat signifikansi alpha 5\%. Berdasarkan hal tersebut maka dapat disimpulkan bahwa variabel GDP Indonesia memiliki pengaruh positif terhadap nilai ekspor India ke Indonesia.

Variabel rata-rata biaya transportasi ekspor India ke Indonesia memiliki memiliki nilai thitung sebesar 0,086 atau $8,6 \%$. Nilai tersebut berada di atas signifikansi alpha 5\%. Berdasarkan hal tersebut maka dapat disimpulkan bahwa variabel rata-rata biaya transportasi tidak memiliki pengaruh terhadap variabel nilai ekspor India ke Indonesia. Variabel penerapan AIFTA memiliki nilai thitung sebesar 0,367 atau $36,7 \%$. Nilai tersebut berada di atas tingkat signifikansi alpha 5\%. Berdasarkan hal tersebut maka dapat disimpulkan bahwa variabel penerapan AIFTA tidak memiliki pengaruh terhadap nilai ekspor India ke Indonesia.

Koefisien regresi variabel independen penerapan AIFTA memiliki koefisien 108,5912 dengan range $-130,963$ dan 348,1453 dengan tingkat keyakinan 95\%. Hal tersebut berarti jika variabel bebas lain diasumsikan konstan, maka nilai ekspor India ke Indonesia diestimasikan akan berubah antara -US\$130.963.000 sampai dengan US\$348.145.300 setelah dilakukan penerapan AIFTA.

Dengan demikian dapat disimpulkan bahwa bahwa Ho: Kesepakatan AIFTA tidak memiliki pengaruh terhadap ekspor Indonesia ke India, dinyatakan diterima.

\subsection{Pengaruh Rata-rata Biaya Transportasi terhadap Perdagangan Indonesia dan India}

Berdasarkan penelitian yang telah dilakukan, dapat disimpulkan bahwa pertumbuhan rata-rata biaya transportasi tidak memiliki pengaruh terhadap pertumbuhan nilai ekspor Indonesia ke India. Hal tersebut berarti bahwa pertumbuhan nilai ekspor Indonesia ke India tidak terkena dampak, baik negatif maupun positif, akibat pertumbuhan biaya transportasi. Pertumbuhan nilai ekspor Indonesia ke India lebih disebabkan oleh faktor-faktor lain selain fluktuasi biaya transportasi.

Hal serupa juga terjadi pada ekspor India ke
Indonesia. Berdasarkan penelitian, dapat disimpulkan bahwa rata-rata biaya transportasi tidak memiliki pengaruh terhadap nilai ekspor India ke Indonesia. Hal tersebut berarti bahwa pertumbuhan nilai ekspor India ke Indonesia tidak terkena dampak, baik negatif maupun positif, akibat pertumbuhan biaya transportasi. Nilai ekspor India ke Indonesia lebih dipengaruhi oleh faktor-faktor selain rata-rata biaya transportasi.

Variabel rata-rata biaya transportasi tidak memiliki pengaruh terhadap nilai ekspor Indonesia ke India dan India ke Indonesia dapat disebabkan karena biaya transportasi merupakan biaya yang menjadi komponen pembentuk harga barang dan pasti telah diperhitungkan sebelumnya oleh konsumen di negara tujuan. Menurut Hummels (2007), konsumen sensitif terhadap perubahan atas harga barang ekspor, bukan terhadap perubahan biaya transportasi barang. Jika biaya transportasi hanya sebagian kecil dari total harga barang ekspor, maka hal-hal seperti kecepatan dan keandalan transportasi menjadi perhatian yang lebih penting bagi konsumen dibandingkan dengan biaya transportasi.

Hal yang perlu diperhatikan di dalam transportasi angkutan barang luar negeri adalah besarnya selisih rata-rata biaya transportasi ekspor Indonesia ke India dan ekspor India ke Indonesia. Ratarata biaya transportasi untuk mengangkut barang ekspor Indonesia ke India berkisar antara US\$2,6$6,7 /$ ton. Sementara rata-rata biaya transportasi untuk mengangkut barang ekspor India ke Indonesia berkisar antara US\$42,3-109,8/ton. Rasio rata-rata biaya transportasi ekspor India ke Indonesia dan ekspor dari Indonesia ke India menurut perhitungan penulis mencapai 9,25 -25,6 kali.

Disparitas yang sangat besar tersebut terjadi karena penulis menggunakan data transaksi jasa pada Neraca Pembayaran Indonesia. Bank Indonesia mencatat transaksi berjalan sebesar jumlah uang yang dibayarkan kepada pengusaha pelayaran nasional. Defisit neraca berjalan dari sektor jasa transportasi barang disebabkan oleh banyaknya eksportir India dan bahkan Indonesia yang menggunakan jasa pelayaran luar negeri sehingga transaksi jasa tersebut tercatat di negara asal angkutan laut/udara. 


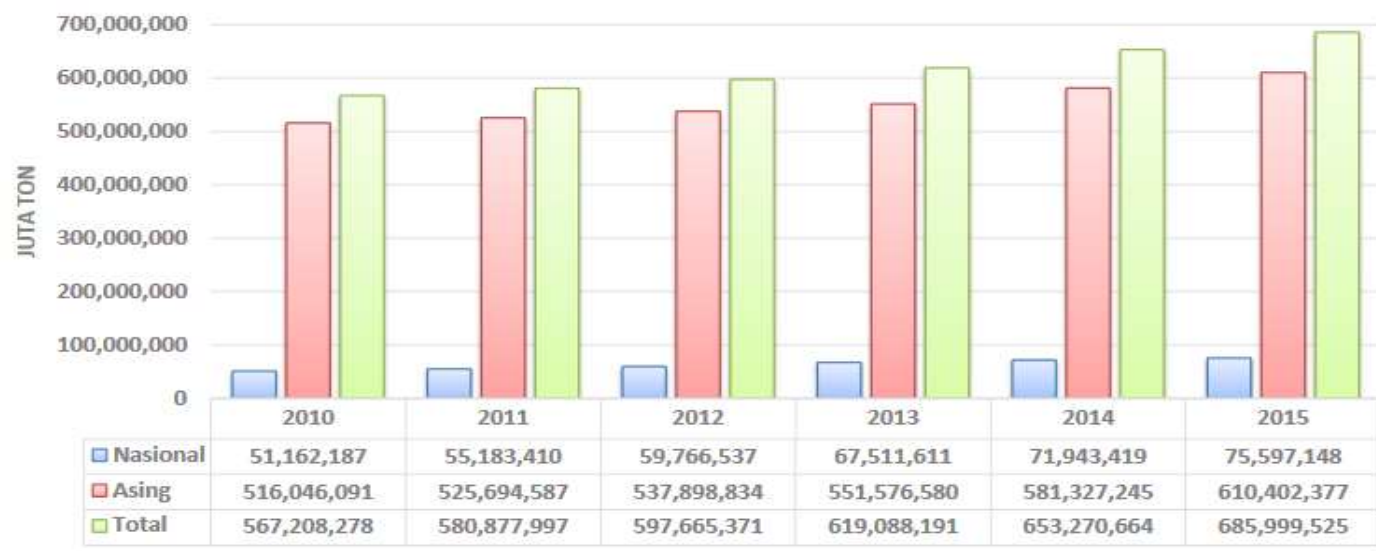

Grafik III.4. Pangsa Muatan Angkutan Luar Negeri

Sumber: Indonesia National Shipowner Association dan Kementerian Perhubungan (2018)

Berdasarkan data dari Asosiasi Pemilik Kapal Nasional/Indonesian National Shipowner Association (INSA) yang disadur dari Kementerian Perhubungan Indonesia, pangsa muatan angkutan luar negeri sebagian besar dikuasai oleh perusahaan pelayaran asing. Seperti ditunjukkan pada grafik III.4, perusahaan asing menguasai $88-90 \%$ dari pangsa muatan angkutan luar negeri berdasarkan tonase. Hasil tersebut menyebabkan data transaksi transportasi ekspor yang ada di transaksi berjalan tidak mencerminkan keseluruhan data transaksi ekspor nasional, perkiraan dari INSA, hanya 10-11\% dari keseluruhan nilai transaksi ekspor yang sesungguhnya. Nilai tersebut sudah membaik dibandingkan periode 1987-1995. Anita (1999) mencatat pada periode tersebut, pangsa muatan angkutan luar negeri hampir 95\% dikuasai oleh pelayaran asing.

Rendahnya daya saing perusahaan pelayaran nasional di sektor angkutan luar negeri memberikan tantangan bagi pemerintah di dalam merumuskan kebijakan. Kebijakan yang tepat dapat mendorong eksportir Indonesia dan bahkan India untuk dapat menggunakan perusahaan pelayaran nasional. Semakin banyaknya eksportir yang menggunakan perusahaan pelayaran nasional tentu akan mengurangi defisit transaksi berjalan dari sektor jasa transportasi barang. Kebijakan untuk meningkatkan pangsa muatan angkutan luar negeri bagi perusahaan pelayaran nasional dapat berupa kewajiban ekspor untuk komoditas-komoditas tertentu menggunakan kapal nasional, pemberian insentif perpajakan, pemberian kemudahan perizinan bagi industri perkapalan nasional, meningkatkan efisiensi dan efektifitas pelabuhan di Indonesia dan lain-lain.

\subsection{Pengaruh GDP terhadap Perdagangan Indonesia - India}

Berdasarkan penelitian yang telah dilakukan, dapat disimpulkan bahwa pertumbuhan GDP Indonesia memiliki pengaruh positif terhadap pertumbuhan nilai ekspor India ke Indonesia. Sebaliknya, Pertumbuhan GDP India akan berimplikasi positif pada pertumbuhan nilai ekspor Indonesia ke India. GDP adalah cerminan dari produktifitas suatu negara dalam menghasilkan barang dan jasa. Semakin tinggi GDP suatu negara umumnya akan disertai oleh peningkatan konsumsi barang dan jasa yang dihasilkan negara lain.

Komoditas ekspor unggulan Indonesia ke India pada tahun 2017 adalah bahan bakar minyak dan gas, minyak nabati dan hewani, bijih besi, karet, dan kertas. Mayoritas komoditas yang diekspor Indonesia ke India adalah bahan baku. Indonesia memiliki keunggulan kompetitif dalam memproduksi komoditas tersebut, baik karena memiliki sumber bahan baku yang melimpah maupun memiliki teknologi yang lebih baik dalam memproduksi komoditas tersebut. Berkaca pada hal tersebut, apabila pemerintah Indonesia memiliki tujuan untuk meningkatkan ekspor Indonesia ke India maka sebaiknya perhatian lebih difokuskan dengan meningkatkan produksi komoditas-komoditas yang memiliki keunggulan kompetitif di pasar India.

Hal lain yang terkait dengan perdagangan Indonesia dengan India adalah cara bagaimana neraca perdagangan Indonesia dicatat. Neraca perdagangan mencatat selisih antara nilai ekspor dan impor Indonesia dalam suatu periode tertentu. Neraca perdagangan sering dijadikan indikasi kinerja perdagangan internasional Indonesia. Namun, bila dicermati lebih lanjut, ada kritik terhadap asumsi dan sudut pandang yang digunakan di dalam melakukan pencatatan neraca perdagangan Indonesia.

Ekspor Indonesia dicatat sebesar nilai barang pada saat dimuat di sarana pengangkut atau umumnya disebut Free on Board. Pencatatan semacam ini mengasumsikan bahwa ketika eksportir Indonesia melakukan ekspor, maka biaya insurance dan freight dibayarkan kepada pihak asing. Sementara itu, nilai impor Indonesia dicatat sebesar nilai Cost, Insurance, and Freight. Hal yang sama juga 
terjadi ketika importir di Indonesia melakukan impor, biaya insurance dan freight juga diasumsikan dibayarkan kepada pihak asing. Ketika melakukan pencatatan neraca perdagangan, asumsi yang dipakai adalah jasa insurance dan freight yang dipakai oleh importir dan eksportir adalah jasa asuransi dan transportasi yang berbasis di luar negeri. Besaran insurance dan freight kurang lebih sekitar 10-15\% dari harga barang. Ketika menghitung neraca perdagangan dengan ukuran ekspor dan impor yang tidak apple to apple seperti dilakukan selama ini, maka hasil yang didapatkan akan menjadi bias.

Komoditas ekspor unggulan India ke Indonesia pada tahun 2017 adalah besi dan baja, kendaraan, bahan kimia, mesin, dan biji-bijian. India memiliki keunggulan kompetitif di dalam memproduksi barang-barang tersebut karena memiliki sumber bahan baku yang melimpah maupun memiliki teknologi yang lebih baik di dalam memproduksi komoditas tersebut.

Mayoritas barang yang diekspor India ke Indonesia merupakan barang jadi. Hal tersebut berkebalikan dengan Indonesia yang kebanyakan melakukan ekspor bahan baku ke India. India menjadikan Indonesia sebagai negara penghasil bahan baku untk kebutuhan industri yang dimilikinya. Hal tersebut menjadi tantangan bagi pemerintah dan masyarakat pelaku bisnis untuk mampu mengekspor tidak hanya bahan baku namun juga barang jadi dan juga barang setengah jadi. Pemerintah dan sektor swasta harus mampu membangun industri-industri pengolahan bahan baku menjadi barang jadi maupun setengah jadi yang memiliki keunggulan kompetitif di pasar internasional. Dengan meningkatkan ekspor barang setengah jadi dan barang jadi, maka Indonesia akan memperoleh keuntungan berupa nilai tambah jika dibandingkan dengan hanya mengekspor bahan baku.

\subsection{Pengaruh Penerapan AIFTA terhadap Perdagangan Indonesia dan India}

Berdasarkan penelitian yang telah dilakukan, dapat disimpulkan bahwa penerapan kesepakatan AIFTA tidak memiliki pengaruh terhadap pertumbuhan nilai ekspor Indonesia ke India. Hal tersebut menggambarkan bahwa penerapan kesepakatan AIFTA tidak berdampak apa-apa terhadap ekspor Indonesia ke India. Dari sudut pandang Indonesia, dapat dikatakan bahwa tujuan dan semangat awal penerapan AIFTA, yaitu untuk meningkatkan perdagangan, dalam hal ini ekspor Indonesia ke India, tidak tercapai.

Hal sebaliknya terjadi pada ekspor India ke
Indonesia. Berdasarkan penelitian, dapat disimpulkan bahwa penerapan kesepakatan AIFTA juga tidak memiliki pengaruh positif terhadap nilai ekspor India ke Indonesia. Hal tersebut berarti bahwa peningkatan nilai ekspor India ke Indonesia sejak tahun 2010 tidak dipengaruhi kebijakan AIFTA. Kedua negara telah sama-sama kehilangan potensi penerimaan negara berupa bea masuk dengan tujuan untuk meningkatkan pertumbuhan ekonomi melalui pertumbuhan perdagangan antara kedua negara. Namun, data-data yang telah dikumpulkan dari lapangan dan dianalisis menunjukkan bahwa AIFTA tidak membawa keuntungan bagi para partner dagang. Penerapan AIFTA tidak berdampak positif terhadap pertumbuhan nilai ekspor Indonesia ke India demikian pula sebaliknya.

Alternatif penjelasan terhadap fenomena tidak berpengaruhnya AIFTA terhadap ekspor Indonesia tersebut adalah karena sebelum AIFTA diterapkan, tingkat ekspor Indonesia dari India telah mencapai pola normal. Ketika perdagangan dua negara sudah mencapai titik normal, maka ruang bagi pertumbuhan perdagangan akan semakin sempit. Dengan ruang untuk bertumbuh yang kecil, maka kebijakan untuk meningkatkan perdagangan melalui skema penurunan tarif menjadi tidak efektif.

Gravity model dapat digunakan untuk mengetahui apakah perdagangan antara dua negara telah mencapai tingkat normal atau belum. Pertumbuhan riil dan normal dari nilai ekspor Indonesia ke India dapat dilihat pada Grafik III.5. Garis biru menggambarkan pertumbuhan riil dan garis oranye menggambarkan pertumbuhan normal ekspor Indonesia ke India. Mayoritas pertumbuhan riil ekspor Indonesia ke India berada di atas pertumbuhan normal ekspor Indonesia.

Bila dikategorikan berdasarkan penerapan AIFTA pada tahun 2010, maka sebelum AIFTA diterapkan pertumbuhan riil ekspor Indonesia ke India telah melewati pertumbuhan ekspor yang normal. $73,91 \%$ dari data pertumbuhan riil ekspor yang diobservasi telah melewati pertumbuhan normalnya. Ketika pertumbuhan riil telah melewati pertumbuhan normal, maka ruang untuk kembali bertumbuh semakin kecil.

Ruang untuk bertumbuh yang kecil dapat kita lihat pada grafik di atas setelah AIFTA diterapkan pada tahun 2010, pertumbuhan riil nyaris selalu berada di atas pertumbuhan normal. 90,91\% dari data pertumbuhan riil ekspor yang diobservasi memiliki nilai yang lebih tinggi daripada nilai normalnya. Hal tersebut membuktikan bahwa penerapan AIFTA tidak memberikan pengaruh terhadap pertumbuhan ekspor Indonesia ke India 


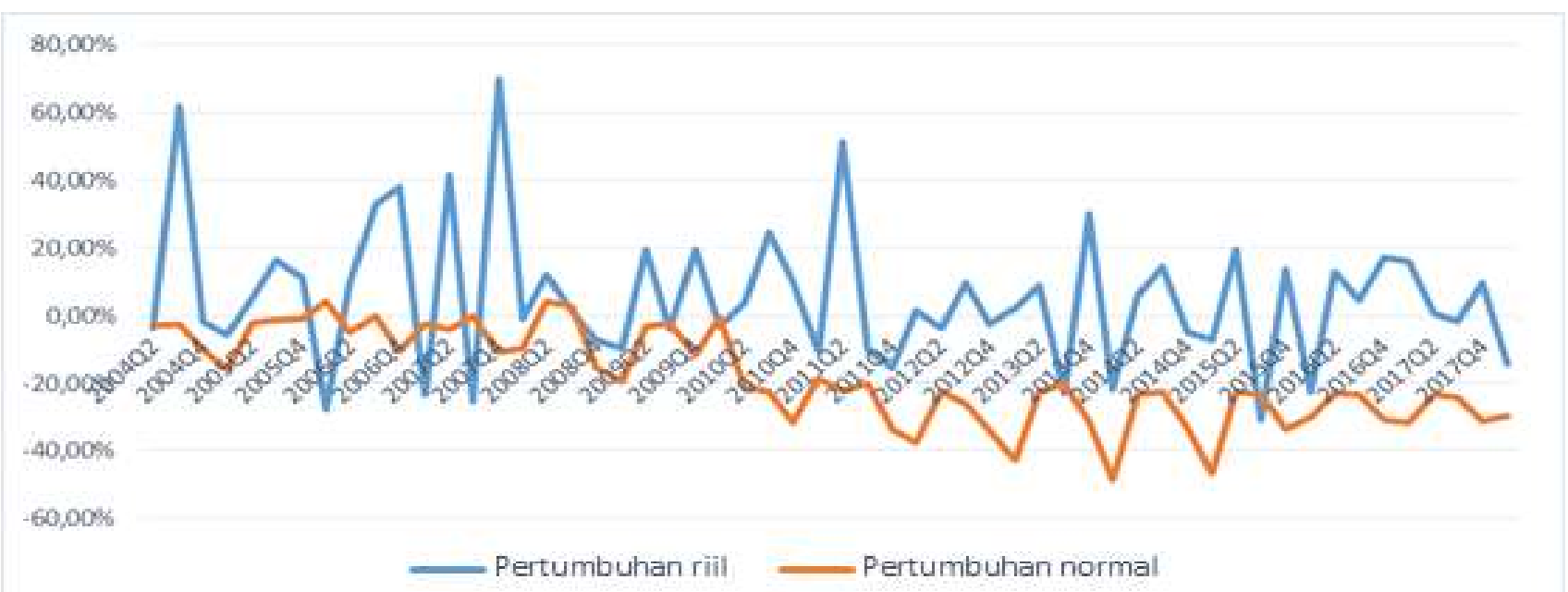

Grafik III.5. Pertumbuhan Riil dan Normal Nilai Ekspor Indonesia ke India Sumber: BPS dan Bank Indonesia diolah menggunakan Excel 2017

Di sisi lain, dari Grafik III.6. dapat dilihat bahwa penerapan AIFTA sejak tahun 2010 terhadap arus barang dari India ke Indonesia cenderung melebihi titik normal, kecuali untuk tahun 20152016. Warna biru menggambarkan nilai riil ekspor India ke Indonesia, dan warna oranye menggambarkan nilai normal ekspor India ke Indonesia. Mayoritas nilai riil ekspor India ke Indonesia berada di atas nilai normal ekspor India ke Indonesia.

Sebelum AIFTA diterapkan pada tahun 2010, pertumbuhan riil ekspor India ke Indonesia belum melewati nilai ekspor India ke Indonesia yang normal. Hanya 29\% dari data nilai riil ekspor India ke
Indonesia yang diobservasi yang telah mencapai nilai normalnya, sementara $71 \%$ sisanya belum mencapai nilai normalnya. Ketika pertumbuhan riil belum mencapai pertumbuhan normal, maka akan banyak ruang untuk peningkatan ekspor India ke Indonesia. Pemberian stimulus berupa skema penurunan tarif dalam kondisi seperti ini akan efektif di dalam meningkatkan volume perdagangan antar negara. Fenomena yang terjadi, setelah diberlakukan AIFTA, ekspor India ke Indonesia tumbuh dengan cepat hingga melebihi nilai normalnya. Pada saat seperti ini penurunan tarif bea masuk tidak lagi menjadi stimulus yang menarik.

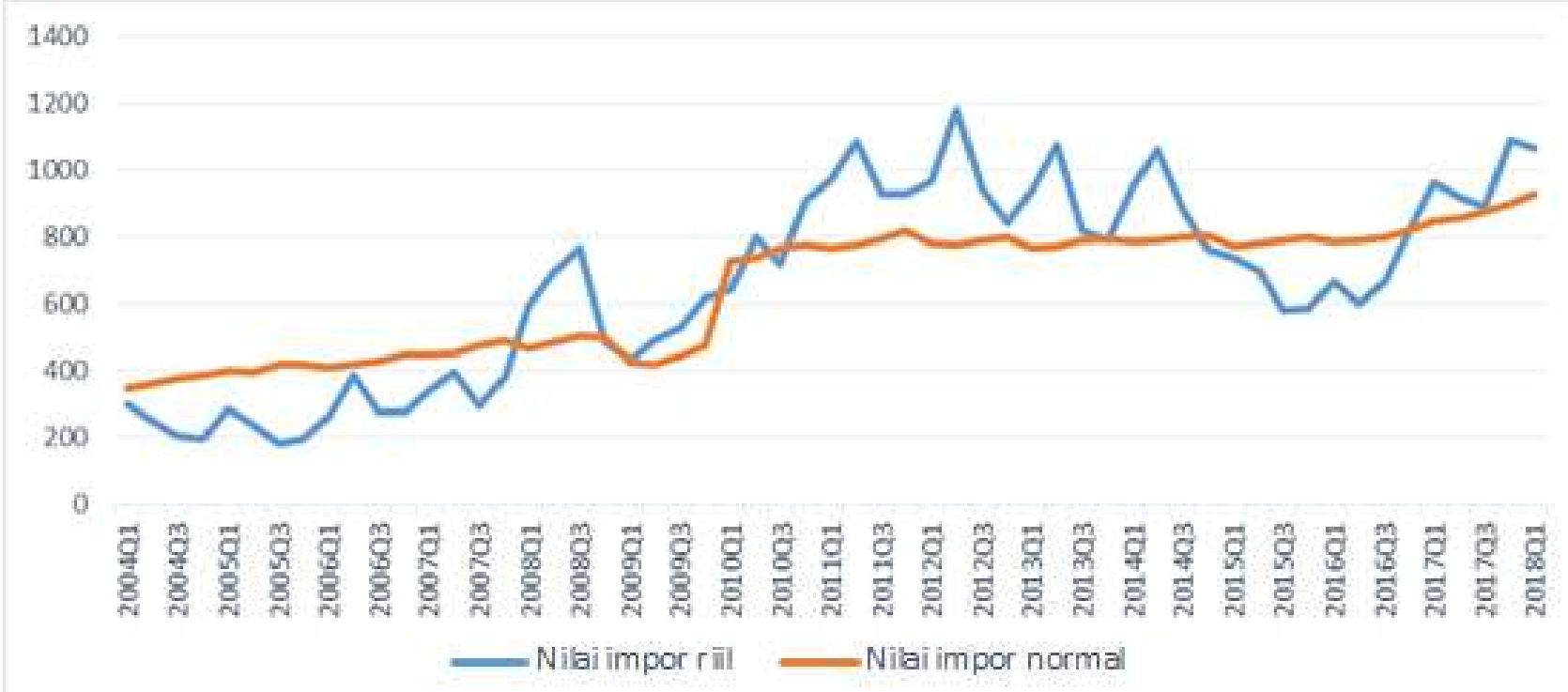

Grafik III.6. Nilai Riil dan Normal Ekspor India ke Indonesia Sumber: BPS dan Bank Indonesia diolah menggunakan Excel 2017 


\section{KESIMPULAN}

Penelitian ini bertujuan untuk mengetahui pengaruh penerapan kesepakatan AIFTA terhadap perdagangan Indonesia dan India. Data yang digunakan merupakan data dalam periode 57 triwulan sejak triwulan pertama 2004 sampai dengan triwulan pertama 2018. Berdasarkan hasil penelitian dapat ditarik kesimpulan sebagai berikut:

1. Biaya transportasi barang ekspor Indonesia ke India dan India ke Indonesia tidak memiliki pengaruh terhadap nilai ekspor Indonesia ke India dan India ke Indonesia. Hal tersebut disebabkan oleh biaya transportasi merupakan salah satu komponen di dalam pembentukan harga barang dan biaya transportasi besarnya tidak signifikan jika dibandingkan dengan harga komoditas. Hal yang perlu jadi perhatian adalah tingginya pangsa pasar asing di dalam penguasaan muatan angkutan barang luar negeri yang hampir mencapai 90\%. Hal tersebut menunjukkan lemahnya daya saing perusahaan pelayaran nasional di dalam pengangkutan barang luar negeri.

2. GDP India memiliki pengaruh positif terhadap ekspor Indonesia ke India. Pertumbuhan ekspor Indonesia akan mengalami peningkatan sebesar 0,504\% sampai dengan 1,379\% untuk setiap 1\% pertumbuhan GDP India. Kenaikan permintaan ekspor Indonesia ke India sangat dipengaruhi oleh peningkatan GDP India. Sebaliknya, peningkatan GDP Indonesia juga berdampak pada kenaikan permintaan ekspor India ke Indonesia, akan tetapi tidak sereaktif permintaan India ke Indonesia. Setiap peningkatan 1\% GDP Indonesia hanya meningkatkan permintaan atas barang-barang dari India sebesar 0,0015\% sampai dengan 0,0053\%.

3. Penerapan AIFTA tidak memiliki pengaruh positif terhadap pertumbuhan ekspor Indonesia ke India dan juga ekspor India ke Indonesia. Hal tersebut terjadi karena nilai ekspor Indonesia ke India, vice versa, sudah mencapai titik normal, sehingga pemberian stimulus berupa penurunan tarif untuk meningkatkan perdagangan menjadi tidak efektif untuk meningkatkan perdagangan Indonesia-India.

\section{IMPLIKASI DAN KETERBATASAN}

Berdasarkan simpulan di atas kiranya perlu dipertimbangkan hal-hal berikut:

1. Pemerintah perlu mendorong dan memberi kesempatan bagi perusahaan pelayaran nasional untuk dapat bersaing dengan perusahaan pelayaran asing. Defisit transaksi berjalan dari jasa transportasi jasa angkutan merupakan salah satu defisit transaksi berjalan yang besar. Kebijakan strategis harus dapat dirumuskan oleh pemerintah guna mendukung bangkitnya industri pelayaran nasional, seperti kewajiban menggunakan perusahaan pelayaran nasional untuk komditas-komoditas tertentu, pemberian insentif perpajakan bagi perusahaan pelayaran, pemberian kemudahan perijinan bagi perusahaan pelayaran, dan lain-lain.

2. Kebijakan AIFTA perlu dikaji kembali efektifitasnya. Kebijakan pemerintah untuk memasuki sebuah perjanjian dagang harus memperhitungkan banyak hal. GDP negara mitra, GDP Indonesia, tingkat perdagangan saat ini, tingkat perdagangan yang normal, dan lain-lain harus menjadi faktor yang dipertimbangkan sebelum memasuki sebuah skema perjanjian dagang. Memasuki sebuah perjanjian dagang di saat nilai perdagangan Indonesia sudah normal bukanlah sebuah kebijakan yang tepat. Untuk itu, perlu dilakukan evaluasi apakah skema-skema perjanjian dagang, tidak hanya AIFTA, yang telah dilakukan Indonesia telah mencapai tujuan awal dari perjanjian dagang tersebut.

\section{DAFTAR PUSTAKA}

Amaliawati, Lia dan Asfia Murni. Pengaruh ASEANChina Free Trade Area (ACFTA) pada Perdagangan Indonesia. Universitas Widyatama

Baier, Scott L. and Jeffrey H. Bergstand. 2005. Do Free Trade Agreements Actually Increase Members' International Trade? South Carolina: Clemson University

Batra, Amita. 2007. India's Global Trade Potential: The Gravity Model Approach. London: Routledge

Bergstand, Jeffrey H. 1985. The Gravity Equation in International Trade: Some Microeconomic Foundations and Empirical Evidence. Massachusets: MIT Press

Bussiere, Matthieu et. al. 2008. EU Enlargement and Trade Integration: Lessons from a Gravity Model. Oxford: Blackwell Publishing Ltd.

Francis, Smitha. 2011. The ASEAN-India Free Trade Agreement: A sectoral impact analysis of increased trade integration in goods. New Delhi: Economic and Political Weekly

Gujarati, Damodar N dan Dawn C, Porter. 2015. Dasar-dasar Ekonometrika Buku 1. Edisi ke-5. Penerj: Eugenia Mardanugraha dkk. Jakarta: Salemba Empat.

Hummels, David. 2007. Transportation Costs and International Trade in the Second Era of Globalization. Indiana: Journal of Economic Perspective

Ibrahim, dkk. 2010. Dampak Pelaksanaan ACFTA Terhadap Perdagangan Internasional Indonesia. Jakarta: Bank Indonesia 
Konstantinos Kepaptsoglou et. al. 2009. Free Trade Agreement Effects in the Mediterranean Region. Washington: Transportation Research Board of the National Academies

Konstantinos Kepaptsoglou et. al. 2010. The Gravity Model Specification for Modeling International Trade Flows and Free Trade Agreement Effects: A 10-Year Review of Empirical Studies. Athens: The Open Economic Journal

Leibenstein, Harvey. Shaping the World Economy: Suggestions for an International Economic Policy by J. Tinbergen. London: Royal Economic Society

Markusen, James R. et. al. 1995. International Trade: Theory and Evidence. United States: McGrow-Hill Inc.

Michael Holden Economics Division. 2003. Stages of Economic Integration: From Autarky to Economic Union. Canada: Parliament of Canada

Pal, Parthapratim dan Mitali Dasgupta. 2009. The ASEAN-India Free Trade Agreement: An Assessment. Economic and Political Weekly

Ristianingrum, Anita. 1999. Analisis Permintaan, Penawaran, dan Efisiensi Jasa Transportasi Laut Sebagai Upaya Mengurangi Defisit Transaksi Berjalan. Bogor: Institut Pertanian Bogor

Sekaran, Uma. 2015. Metodologi Penelitian untuk Bisnis Buku 1 Edisi 4. Jakarta: Penerbit Salemba Empat

Setiawan, Hendy Noviansyah. 2017. Skripsi. Analisis Pengaruh Penerapan Indonesia Japan Economic Partnership Agreement, GDP Jepang, dan Nilai Kurs terhadap Nilai Ekspor Indonesia ke Jepang. Jakarta

Tinbergen, Jan. 1962. Shaping the World Economy. New York: Twentieh Century Fund

Trefler, Daniel. 2004. The Long and Short of the Canada-U.S. Free Trade Agreement. Toronto: University of Toronto 